CORRESPONDENCE.

\title{
UNIFORM SENIORITY AND LAST SURVIVOR ANNUITIES:-
}

(PKOOF THAT, IF $a_{x y}=a_{w, w}, a_{x y} \neq a_{\overline{w w}}$ ).

To the Editor of the Journal of the Institute of Actuaries.

DEAR SIR,--It is well known that when a mortality table follows Makeham's Law we can find an age $w$ such that $a_{x: y}=a_{w: w}$, and beginners sometimes fall into the error of supposing from this that in such circumstances $a_{x: 3}$ and $a_{w: v}$ are similarly related.

The following demonstration may therefore be of interest to some of your readers :-

$$
\text { If } a_{x: y}=a_{z: a v} \text { then }{ }_{t} p_{x: y}={ }_{t} p_{w: w} \text { for all values of } t
$$

and

$$
\bar{t}_{x: y}=\bar{a}_{w: w} .
$$

Similarly, if $a_{x: y}$ were equal to $a_{w: w}$, we should have $t_{x: y}=\overline{t_{r: m}}$ or

$$
\bar{a}_{x}+\bar{t}_{y}-\bar{t}_{x: y}=3 \bar{t}_{w}-\bar{\theta}_{w} ; w
$$

or, (since $\bar{a}_{x: y}=\bar{a}_{z w}: z$ ) $\quad \bar{a}_{x}+\bar{a}_{y}=2 \bar{a}_{z w}$.

It is fairly obvious that as a rule these two different relationships between $x, y$ and $w$, cannot hold good, but a formal proof can be furnished as follows: 
Differentiating (1) with respect to age, we get

$$
\bar{a}_{x: y}\left(\mu_{x: y}+\delta\right)-1=\bar{a}_{w: w}\left(\mu_{w: w}+\delta\right)-1 ;
$$

whence (remembering that $\bar{a}_{x: y}=\bar{a}_{w: v}$ ) $\mu_{x: y}=\mu_{z: v}$. or

$$
\mu_{x}+\mu_{y}=2 \mu_{c c} \text {. }
$$

Differentiating (2) we get

$$
\bar{a}_{x}\left(\mu_{x}+\delta\right)-1+\bar{a}_{y}\left(\mu_{y}+\delta\right)-1=2 \bar{a}_{w}\left(\mu_{w}+\delta\right)-2
$$

and substituting for $\bar{a}_{w}$ and $\mu_{v}$ their values from (2) and (3)

$$
\bar{a}_{x} \mu_{x}+\bar{a}_{y, \mu_{y}}=\left(\bar{a}_{x}+\bar{a}_{y}\right)\left(\frac{\mu_{x}+\mu_{y}}{2}\right)
$$

multiplying out, this reduces to

or

$$
\begin{aligned}
& \bar{a}_{x} \mu_{x}+\bar{a}_{y} \mu_{y}=\bar{a}_{x} \mu_{y}+\bar{a}_{y} \mu_{x} \\
& \bar{a}_{x}\left(\mu_{x}-\mu_{y}\right)=\bar{a}_{y}\left(\mu_{x}-\mu_{y}\right)
\end{aligned}
$$

which cannot be true untess $\bar{a}_{x}=\bar{a}_{y}$, or $\mu_{x}=\mu_{y}$

and neither of these relations can hold unless $x=y$, or $\mu$ is constant. Now $\mu$ is not constant, but increases with the age, the increase being very rapid at advanced ages, therefore the equations

\begin{tabular}{|c|c|c|c|c|c|}
\hline$x$ & $y$ & $w$ & $a_{\overrightarrow{1 r}: w}$ & $a_{x=y}$ & Error \\
\hline $\begin{array}{l}20 \\
\ldots \\
\ldots \\
40 \\
\ldots \\
60 \\
80\end{array}$ & $\begin{array}{l}40 \\
60 \\
80 \\
60 \\
80 \\
80 \\
90\end{array}$ & $\begin{array}{l}34 \\
52 \cdot 6 \\
72 \cdot 3 \\
54 \\
72 \cdot 6 \\
74 \\
86 \cdot 1\end{array}$ & $\begin{array}{r}22 \cdot 463 \\
16 \cdot 390 \\
8 \cdot 363 \\
15 \cdot 449 \\
8 \cdot 245 \\
7 \cdot 702 \\
3 \cdot 716\end{array}$ & $\begin{array}{r}23 \cdot 890 \\
22 \cdot 736 \\
22 \cdot 224 \\
18 \cdot 366 \\
17 \cdot 455 \\
10 \cdot 857 \\
4.395\end{array}$ & $\begin{array}{r}1 \cdot 427 \\
6 \cdot 346 \\
13 \cdot 861 \\
2 \cdot 517 \\
9 \cdot 210 \\
3 \cdot 155 \\
.679\end{array}$ \\
\hline
\end{tabular}

$$
\bar{a}_{x: y}=\bar{a}_{t: w} \text { and } \bar{a}_{x: y}=\bar{a}_{z b: t v}\left(\text { or } a_{x: y}=a_{u: w} \text { and } a_{x: y}=a_{w: w}\right. \text { ) }
$$

cannot both hold good unless $x=y$, when the two sides of each become identical. That the amount of the error may be serious is shown by the following figures taken from the $\mathrm{O}^{\mathrm{M}(5)}$ Table at 3 per-cent, the values of $w$ being calculated to one decimal place :-

It will be noticed that $\overline{a_{w}: w}$ is less than $\bar{a}_{x: y}$ in all cases, and that the difference increases rapidly as the difference between $x$ and $y$ becomes larger. This also appears from the following considerations. The joint life annuity cannot continue longer than the "complement of life" of the older of the two lives, however young the other may be ; therefore the age of the older life is the preponderating factor in determining the joint life annuity value $a_{x: y}$; and this preponderance increases with the difference between $x$ and $y$, until, in the limiting case, when the older life $(y$, say) reaches the limit of 
life, $a_{x: y}=a_{y}$ (both of them being zero), and the age of the younger life has no effect whatever on the value. Accordingly, the substituted age $w$ must be nearer the older than the younger of the two lives, or $w>(x+y): 2$ and the excess increases with the difference between $x$ and $y$. On the other hand the last survivor annuity may continue for the "eomplement of life" of the younger of the two lives, however old the other may be; and the age of the younger is therefore the preponderating factor in this case, and the preponderance increases with the difference between $x$ and $y$ until, in the limit, when $y$ reaches the limit of life, $a_{x: y}=a_{x}$, and the value depends solely on the age of the younger life. Therefore the age $z$ at which $a_{x \overline{x: y}}=a_{\overline{z: z}}$ must be nearer the younger than the older life, or $z<(x+y): 2$. Hence $z$ must be less than $w$, and accordingly $a_{\bar{\omega}, 4}$ greater than $a_{w: w}$, and the difference between them increases with the difference between $x$ and $y$.

Yours faithfully,

A. E. SPRAGUE.

Edinburgh 26 August, 1910.

\section{RELATION BETWEEN RATES OF SICKNESS AND SIZE OF LODGE.}

To the Editor of the Journal of the Institute of Actuaries.

SIR,-One of the most striking features of the monumental work of Mr. Alfred W. Watson, as shown in his paper in J.I. A., xxxv, is the apparent proof that the rates of sickness increase with the size of the lodge, vide the tables shown on pages 289 et seq., and the accompanying remarks. I reproduce Table 16 (p. 291).

TABLE 16.

\begin{tabular}{|c|c|c|c|c|c|c|c|c|}
\hline \multirow{3}{*}{$\begin{array}{l}\text { Number of } \\
\text { Menbers } \\
\text { in the } \\
\text { Lodge }\end{array}$} & \multirow{3}{*}{$\begin{array}{l}\text { Total } \\
\text { No. of } \\
\text { Lodges } \\
\text { in the } \\
\text { gloup }\end{array}$} & \multirow{3}{*}{$\begin{array}{c}\text { Pereet tage } \\
\text { of the } \\
\text { whole } \\
\text { number of } \\
\text { Lodges }\end{array}$} & \multicolumn{6}{|c|}{ SICKNESB COST } \\
\hline & & & \multicolumn{2}{|c|}{ HIGH } & \multicolumn{2}{|c|}{ NormaI } & \multicolumn{2}{|c|}{ Low } \\
\hline & & & $\begin{array}{l}\text { No. of } \\
\text { Lodges }\end{array}$ & $\begin{array}{l}\text { Percentage } \\
\text { of the } \\
\text { number of } \\
\text { Lodges in } \\
\text { the gronp }\end{array}$ & $\begin{array}{l}\text { No. of } \\
\text { Lodges }\end{array}$ & $\begin{array}{l}\text { Pereentage } \\
\text { of the } \\
\text { number of } \\
\text { Lodges in } \\
\text { the group }\end{array}$ & $\begin{array}{l}\text { No. of } \\
\text { Lodges }\end{array}$ & $\begin{array}{l}\text { Percentage } \\
\text { of the } \\
\text { number of } \\
\text { Lodges in } \\
\text { the group }\end{array}$ \\
\hline Under 80 & 823 & 23 & 337 & $\begin{array}{c}\text { Per cent } \\
41\end{array}$ & 255 & $\begin{array}{c}\text { Per cent. } \\
31\end{array}$ & 231 & $\begin{array}{c}\text { Per cent } \\
28\end{array}$ \\
\hline $80-149$ & 1,059 & 30 & 543 & 51 & 314 & 30 & 202 & 19 \\
\hline $150-249$ & 877 & 24 & 504 & 57 & 212 & 24 & 161 & 19 \\
\hline $250-349$ & 425 & 12 & 278 & 66 & 87 & 20 & 60 & 14 \\
\hline $350 \quad 489$ & 279 & 8 & 206 & 74 & 47 & 17 & 26 & 9 \\
\hline $\begin{array}{c}500 \text { and } \\
\text { over }\end{array}$ & 118 & 3 & 97 & 82 & 11 & 9 & 10 & 9 \\
\hline$\cdots$ & 3,581 & 100 & 1,965 & 55 & 926 & 26 & 690 & 19 \\
\hline
\end{tabular}

